\title{
QUANTITATIVE ANTIBODY STUDIES IN MAN. III. ANTIBODY RESPONSE IN LEUKEMIA AND OTHER MALIGNANT LYMPHOMATA 1
}

\author{
BY DANIEL L. LARSON 2 AND LOIS J. TOMLINSON \\ (From the Department of Medicine, Columbia University College of Physicians and Surgeons, \\ and the Presbyterian Hospital, New York, N. Y.)
}

(Submitted for publication November 18, 1952; accepted December 24, 1952)

The lymphocyte, the plasma cell and the cells of the reticuloendothelial system have been described as sites of antibody formation in animals (1-5). Since the malignant lymphomata in man are often associated with an increase in the number of these cells, studies were initiated to determine if abnormalities in antibody response occurred in patients with leukemia, lymphosarcoma or Hodgkin's disease.

Several reports have appeared in the literature describing the ability to form antibodies in patients with leukemia and related diseases. Antigens used have included typhoid organisms (6-9), vibrio vaccine $(10)$, and horse serum $(11,12)$. Antibody responses, measured by methods based on serum dilution techniques, suggested an impairment of antibody formation in patients with chronic leukemia, especially in those with chronic lymphatic leukemia. Heterophile antibody titers have been studied in patients with leukemia and allied diseases, and the data have recently been reviewed $(13,14)$. The evidence indicates that the incidence of elevated heterophile antibody titers is not increased in the leukemias. The purpose of this communication is to report observations on antibody formation in human leukemia, lymphosarcoma and Hodgkin's disease, using the quantitative precipitin technique developed by Heidelberger and his associates (15).

\section{METHODS}

None of the patients who served as subjects in this study received radiotherapy, nitrogen mustard or folic acid antagonists for a period of at least six months before the test period. During the test period a few of the subjects were given supportive blood transfusions. Patients with acute leukemia treated with cortisone were

1 This study has been aided by a grant from the American Cancer Society on recommendation of the National Research Council.

2 John and Mary R. Markle Scholar in Medical Science. started on the drug several days to several weeks before the test period and were maintained on the drug in dosage of $\mathbf{1 0 0}$ to $\mathbf{3 0 0}$ milligrams by mouth per day throughout the test period. No attempt was made to classify the diagnosis in patients with acute leukemia into the lymphatic and myeloid forms. After obtaining a preliminary blood sample, the patients were given 0.08 milligram each of type-specific pneumococcus capsular polysaccharides I and II subcutaneously. Several post-immunization blood samples were obtained, and the highest post-immunization titer observed is reported as the antibody response. Analyses for C-antibody and antibody to the capsular polysaccharides were carried out according to the method described by Heidelberger and his associates (15). With this method, the de-fatted serum is first treated with crystalline egg albumin and rabbit anti-egg albumin serum to remove the complement. The $\mathrm{C}$-antibody is then removed from the serum by addition of $\mathrm{C}$-polysaccharide derived from a pneumococcus type other than the types used as antigens. The serum is then analyzed for the presence of antibodies to the capsular polysaccharides. Results are expressed as micrograms of precipitable antibody nitrogen per 4 milliliters of serum.

\section{RESULTS}

Previous observations have established that the maximal antibody response to type-specific pneumococcus capsular polysaccharides I and II in humans is usually 10 to 60 micrograms of antibody nitrogen per 4 milliliters of serum $(15,16)$. A few normal individuals have been noted to have postimmunization antibody titers as high as $100 \mathrm{mi}$ crograms, and occasionally little or no antibody response is detected. ${ }^{3}$ Representative values for antibody response in normal individuals are shown in Table I.

Most of the patients under study had no detectable precipitable antibody to the capsular polysaccharides in the preliminary blood sample. The time of appearance of antibodies following the ad-

3 According to the data in (15) the normal means are 30 and 29 micrograms of antibody nitrogen per 4 milliliters of serum, with a S.D. of 37 and 25 for antibody to SI and SII, respectively. 
TABLE I

Antibody formation in normal man

\begin{tabular}{|c|c|c|c|}
\hline \multirow[b]{2}{*}{ Subject } & \multirow[b]{2}{*}{$\underset{\text { to }^{*}}{\text { Antibody }}$} & \multicolumn{2}{|c|}{$\begin{array}{l}\text { Micrograms of antibody nitrogen } \\
\text { per } 4 \text { milliliters of serum }\end{array}$} \\
\hline & & $\begin{array}{c}\text { Pre- } \\
\text { immunization }\end{array}$ & $\begin{array}{c}\text { Post- } \\
\text { immunization }\end{array}$ \\
\hline 1 & $\begin{array}{ll}\text { C } & \text { III } \\
\text { S } & \text { I } \\
\text { S } & \text { II }\end{array}$ & $\begin{array}{r}46 \\
3 \\
0\end{array}$ & $\begin{array}{l}28 \\
11 \\
11\end{array}$ \\
\hline 2 & $\begin{array}{ll}\text { C III } \\
\text { S I I } \\
\text { S II }\end{array}$ & $\begin{array}{r}21 \\
1 \\
1\end{array}$ & $\begin{array}{l}18 \\
27 \\
23\end{array}$ \\
\hline 3 & $\begin{array}{ll}\text { C III } \\
\text { S I } \\
\text { S II }\end{array}$ & $\begin{array}{r}50 \\
4 \\
1\end{array}$ & $\begin{array}{l}57 \\
30 \\
23\end{array}$ \\
\hline 4 & $\begin{array}{ll}\text { C III } \\
\text { S I } \\
\text { S II }\end{array}$ & $\begin{array}{l}7 \\
0 \\
1\end{array}$ & $\begin{array}{r}6 \\
29 \\
45\end{array}$ \\
\hline 6 & $\begin{array}{ll}\text { C III } \\
\text { S I } \\
\text { S II }\end{array}$ & $\begin{array}{r}32 \\
0 \\
0\end{array}$ & $\begin{array}{r}25 \\
0 \\
6\end{array}$ \\
\hline 9 & $\begin{array}{ll}\text { C III } \\
\text { S I I } \\
\text { S II }\end{array}$ & $\begin{array}{r}18 \\
1 \\
0\end{array}$ & $\begin{array}{r}17 \\
4 \\
7\end{array}$ \\
\hline 11 & $\begin{array}{l}\text { C III } \\
\text { S I } \\
\text { S II }\end{array}$ & $\begin{array}{r}60 \\
1 \\
8\end{array}$ & $\begin{array}{l}62 \\
15 \\
24\end{array}$ \\
\hline 35 & $\begin{array}{ll}\text { C III } \\
\text { S I } \\
\text { S III }\end{array}$ & $\begin{array}{l}7 \\
0 \\
0\end{array}$ & $\begin{array}{r}8 \\
52 \\
96\end{array}$ \\
\hline 39 & $\begin{array}{ll}\text { C III } \\
\text { S I I } \\
\text { S II }\end{array}$ & $\begin{array}{r}26 \\
0 \\
0\end{array}$ & $\begin{array}{l}26 \\
15 \\
22\end{array}$ \\
\hline 40 & $\begin{array}{ll}\text { C III } \\
\text { S I I } \\
\text { S II }\end{array}$ & $\begin{array}{r}39 \\
1 \\
3\end{array}$ & $\begin{array}{r}50 \\
144 \\
61\end{array}$ \\
\hline 41 & $\begin{array}{ll}\text { C III } \\
\text { S I } \\
\text { S II }\end{array}$ & $\begin{array}{r}12 \\
0 \\
0\end{array}$ & $\begin{array}{r}8 \\
9 \\
19\end{array}$ \\
\hline 52 & $\begin{array}{ll}\text { C III } \\
\text { S I } \\
\text { S II }\end{array}$ & $\begin{array}{r}33 \\
0 \\
2\end{array}$ & $\begin{array}{l}48 \\
22 \\
15\end{array}$ \\
\hline
\end{tabular}

* Letter and numeral refer to pneumococcus polysaccharide precipitinogen used, i.e., C III and C VII are the somatic polysaccharides from Type III and Type VII pneumococcus, respectively; S I and S II are the capsular polysaccharides derived from pneumococcus Types I and II, respectively.

ministration of the antigens was similar to that observed in normal individuals. Maximal antibody titers were usually achieved by two weeks following immunization and patients living as long as six months after immunization showed a persistence of these elevated antibody titers. As has been described in normal individuals, there was usually little change in the levels of $\mathrm{C}$-antibody during the test period $(15,16)$.

Nine of 11 patients with untreated acute leukemia produced unusually large amounts of antibody to at least one of the antigens (Table II). Patient 71 was an adult who entered a spontaneous temporary remission during the test period and formed very little antibody. As is shown in Table III, the seven patients with acute leukemia who

TABLE II

Antibody formation in patients with untreated acute leukemia

\begin{tabular}{|c|c|c|c|c|}
\hline \multirow[b]{2}{*}{ Subject } & \multirow[b]{2}{*}{ Age } & \multirow[b]{2}{*}{$\underset{\text { to* }}{\text { Antibody }}$} & \multicolumn{2}{|c|}{$\begin{array}{l}\text { Micrograms of antibody nitrogen } \\
\text { per } 4 \text { milliliters of serum }\end{array}$} \\
\hline & & & $\begin{array}{c}\text { Pre- } \\
\text { immunization }\end{array}$ & $\begin{array}{c}\text { Post- } \\
\text { immunization }\end{array}$ \\
\hline 73 & 39 & $\begin{array}{l}\text { C VII } \\
\text { S I } \\
\text { S II }\end{array}$ & $\begin{array}{r}29 \\
1 \\
1\end{array}$ & $\begin{array}{r}37 \\
537 \\
669\end{array}$ \\
\hline 16 & 32 & $\begin{array}{ll}\text { C III } \\
\text { S I I } \\
\text { S II }\end{array}$ & $\begin{array}{r}39 \\
0 \\
0\end{array}$ & $\begin{array}{c}45 \\
396 \\
563 \dagger\end{array}$ \\
\hline 104 & 38 & $\begin{array}{l}\text { C VII } \\
\text { S I } \\
\text { S II }\end{array}$ & $\begin{array}{r}28 \\
0 \\
1\end{array}$ & $\begin{array}{r}14 \\
624 \\
111\end{array}$ \\
\hline 117 & 38 & $\begin{array}{l}\text { C VII } \\
\text { S I } \\
\text { S II }\end{array}$ & $\begin{array}{r}30 \\
0 \\
14\end{array}$ & $\begin{array}{r}69 \\
121 \\
604\end{array}$ \\
\hline 121 & 32 & $\begin{array}{l}\text { C VII } \\
\text { S I } \\
\text { S II }\end{array}$ & $\begin{array}{r}62 \\
0 \\
0\end{array}$ & $\begin{array}{r}36 \\
25 \\
640\end{array}$ \\
\hline 97 & 61 & $\begin{array}{l}\text { C VII } \\
\text { S I } \\
\text { S II }\end{array}$ & $\begin{array}{r}51 \\
0 \\
9\end{array}$ & $\begin{array}{r}61 \\
122 \\
447\end{array}$ \\
\hline 15 & 19 & $\begin{array}{ll}\text { C } & \text { III } \\
\text { S } & \text { I } \\
\text { S } & \text { II }\end{array}$ & $\begin{array}{r}18 \\
0 \\
0\end{array}$ & $\begin{array}{r}18 \\
78 \\
586\end{array}$ \\
\hline 120 & 15 & $\begin{array}{l}\text { C VII } \\
\text { S I } \\
\text { S II }\end{array}$ & $\begin{array}{r}20 \\
0 \\
0\end{array}$ & $\begin{array}{r}19 \\
47 \\
428\end{array}$ \\
\hline 123 & 45 & $\begin{array}{ll}\text { C VII } \\
\text { S I } \\
\text { S II }\end{array}$ & $\begin{array}{l}7 \\
0 \\
0\end{array}$ & $\begin{array}{r}19 \\
86 \\
374\end{array}$ \\
\hline 118 & 15 & $\begin{array}{l}\text { C VII } \\
\text { S I } \\
\text { S II }\end{array}$ & $\begin{array}{l}8 \\
0 \\
2\end{array}$ & $\begin{array}{l}19 \\
14 \\
20\end{array}$ \\
\hline $71 \ddagger$ & 43 & $\begin{array}{l}\text { C VII } \\
\text { S I } \\
\text { S II }\end{array}$ & $\begin{array}{r}24 \\
1 \\
3\end{array}$ & $\begin{array}{r}23 \\
4 \\
4\end{array}$ \\
\hline
\end{tabular}

* See footnote, Table I.

† Specimen of serum became contaminated in the course of repeated absorptions and this probably represents a value less than the true anti-S II content.

$\ddagger$ Patient entered a period of spontaneous temporary remission during the test period. 
TABLE III

Antibody formation in patients with acute leubemia treated with cortisone

\begin{tabular}{|c|c|c|c|c|}
\hline \multirow[b]{2}{*}{ Subject } & \multirow[b]{2}{*}{ Age } & \multirow{2}{*}{$\underset{\text { to }^{*}}{\text { Antibody }}$} & \multicolumn{2}{|c|}{$\begin{array}{l}\text { Micrograms of antibody nitrogen } \\
\text { per } 4 \text { milliliters of serum }\end{array}$} \\
\hline & & & $\begin{array}{c}\text { Pre- } \\
\text { immunization }\end{array}$ & $\begin{array}{c}\text { Post- } \\
\text { immunization }\end{array}$ \\
\hline 85 & 52 & $\begin{array}{ll}\text { C } & \text { VII } \\
\text { S } & \text { I } \\
\text { S } & \text { II }\end{array}$ & $\begin{array}{r}98 \\
0 \\
0\end{array}$ & $\begin{array}{r}21 \\
284 \\
59\end{array}$ \\
\hline 110 & 61 & $\begin{array}{ll}\text { C } & \text { VII } \\
\text { S } & \text { I } \\
\text { S } & I I\end{array}$ & $\begin{array}{r}43 \\
0 \\
0\end{array}$ & $\begin{array}{r}22 \\
153 \\
116\end{array}$ \\
\hline 107 & 30 & $\begin{array}{ll}\mathbf{C} & \mathrm{VII} \\
\mathbf{S} & \mathrm{I} \\
\mathbf{S} & \mathbf{I I}\end{array}$ & $\begin{array}{r}40 \\
0 \\
0\end{array}$ & $\begin{array}{r}35 \\
141 \\
53\end{array}$ \\
\hline 112 & 73 & $\begin{array}{ll}\text { C } & \text { VII } \\
\text { S } & \text { I } \\
\text { S } & \text { II }\end{array}$ & $\begin{array}{r}54 \\
0 \\
0\end{array}$ & $\begin{array}{r}32 \\
45 \\
148\end{array}$ \\
\hline 108 & 55 & $\begin{array}{ll}\mathrm{C} & \mathrm{VII} \\
\mathbf{S} & \mathbf{I} \\
\mathbf{S} & \mathbf{I I}\end{array}$ & $\begin{array}{r}15 \\
0 \\
0\end{array}$ & $\begin{array}{r}26 \\
8 \\
139\end{array}$ \\
\hline 93 & 53 & $\begin{array}{ll}\text { C VII } & \text { II } \\
\text { S I } & \\
\text { S } & \text { II }\end{array}$ & $\begin{array}{r}16 \\
0 \\
0\end{array}$ & $\begin{array}{r}189 \\
30 \\
62\end{array}$ \\
\hline 111 & 30 & $\begin{array}{l}\text { C VII } \\
\text { S I } \\
\text { S II }\end{array}$ & $\begin{array}{r}25 \\
0 \\
0\end{array}$ & $\begin{array}{l}33 \\
10 \\
67\end{array}$ \\
\hline
\end{tabular}

* See footnote, Table I.

were treated with cortisone showed antibody responses which were often well above the normal range but appeared to be considerably lower than in the untreated group.

In Table IV, data on seven patients with chronic myeloid leukemia indicate an antibody response essentially in the normal range. Eight out of nine patients with chronic lymphatic leukemia exhibited little or no detectable antibody response (Table V). Patient No. 113 had an episode of bacterial pneumonia during the test period, accompanied by a normal antibody response to the administered antigens.

Three patients with Hodgkin's disease and four patients with lymphosarcoma presented a low or normal antibody response (Table VI). Previous studies have indicated (17) that patients with multiple myeloma form little or no antibody to pneumococcus capsular polysaccharides I and II.

\section{DISCUSSION}

The pneumococcus polysaccharide-anti-polysaccharide system has several features which make it different from many other antigen-antibody systems. The antigen is non-protein and it fails to stimulate antibody formation in the rabbit (18). In man, elevated antibody titers may persist for years following a single antigenic stimulation, and in these individuals, an anamnestic response does not occur (19). For these reasons information on antibody response obtained in man using the pneumococcus polysaccharides does not necessarily apply to other antigen-antibody systems or to other species.

The ability to form antibodies to the pneumococcus capsular polysaccharides in these studies appeared to be influenced by the type of leukemia present. Individuals with acute leukemia had the largest number of immature white blood cells in their peripheral blood and bone marrow, and were also noted to have the largest antibody responses. There was no apparent relation between the total white blood cell count in the peripheral blood and the amount of antibody produced. The data do raise the possibility that, in man, the immature white blood cell may play a role in the formation

TABLE IV

Antibody formation in patients with chronic myeloid leukemio

\begin{tabular}{|c|c|c|c|c|}
\hline \multirow[b]{2}{*}{ Subject } & \multirow[b]{2}{*}{ Age } & \multirow[b]{2}{*}{$\underset{\text { to* }}{\text { Antibody }}$} & \multicolumn{2}{|c|}{$\begin{array}{c}\text { Micrograms of antibody nitrogen } \\
\text { per } 4 \text { milliliters of serum }\end{array}$} \\
\hline & & & $\begin{array}{c}\text { Pre- } \\
\text { immunization }\end{array}$ & $\begin{array}{c}\text { Post- } \\
\text { immunization }\end{array}$ \\
\hline 61 & 69 & $\begin{array}{l}\text { C III } \\
\text { S I I } \\
\text { S II }\end{array}$ & $\begin{array}{r}25 \\
0 \\
0\end{array}$ & $\begin{array}{r}71 \\
144 \\
38\end{array}$ \\
\hline 70 & 51 & $\begin{array}{l}\text { C VII } \\
\text { S I } \\
\text { S II }\end{array}$ & $\begin{array}{r}10 \\
0 \\
9\end{array}$ & $\begin{array}{r}15 \\
211 \\
0\end{array}$ \\
\hline 22 & 51 & $\begin{array}{l}\text { C VII } \\
\text { S I } \\
\text { S II }\end{array}$ & $\begin{array}{l}6 \\
0 \\
0\end{array}$ & $\begin{array}{r}0 \\
45 \\
67\end{array}$ \\
\hline 23 & 60 & $\begin{array}{l}\text { C III } \\
\text { S I I } \\
\text { S II }\end{array}$ & $\begin{array}{r}26 \\
4 \\
0\end{array}$ & $\begin{array}{l}21 \\
53 \\
57\end{array}$ \\
\hline 82 & 55 & $\begin{array}{l}\text { C VII } \\
\text { S I } \\
\text { S II }\end{array}$ & $\begin{array}{r}24 \\
0 \\
0\end{array}$ & $\begin{array}{l}51 \\
44 \\
63\end{array}$ \\
\hline 83 & 45 & $\begin{array}{ll}\text { C } & \text { VII } \\
\text { S } & \text { I } \\
\text { S } & \text { II }\end{array}$ & $\begin{array}{r}21 \\
0 \\
0\end{array}$ & $\begin{array}{l}33 \\
26 \\
46\end{array}$ \\
\hline 96 & 62 & $\begin{array}{l}\text { C VII } \\
\text { S I } \\
\text { S II }\end{array}$ & $\begin{array}{r}82 \\
0 \\
0\end{array}$ & $\begin{array}{l}86 \\
24 \\
10\end{array}$ \\
\hline
\end{tabular}

* See footnote, Table I. 
of antibody to the pneumococcus polysaccharides. Other studies $(15,16)$ have indicated that a large antibody response to one antigen is not necessarily accompanied by a similar response to another antigen. This observation is confirmed by the present studies and remains without an explanation.

It has been shown that the administration of cortisone to patients with rheumatoid arthritis has no detectable effect on the level of circulating antibody to pneumococcus polysaccharides when cortisone is given either before or during the period of active immunization (16). In the present studies, cortisone administration to patients with acute leukemia was associated with the production of smaller amounts of antibody than was observed in the group of patients with acute leukemia who

TABLE V

Antibody formation in patients with chronic lymphatic leukemia

\begin{tabular}{|c|c|c|c|c|}
\hline \multirow[b]{2}{*}{ Subject } & \multirow[b]{2}{*}{ Age } & \multirow[b]{2}{*}{$\underset{\text { to* }}{\text { Antibody }}$} & \multicolumn{2}{|c|}{$\begin{array}{l}\text { Micrograms of antibody nitrogen } \\
\text { per } 4 \text { milliliters of serum }\end{array}$} \\
\hline & & & $\begin{array}{c}\text { Pre- } \\
\text { immunization }\end{array}$ & $\begin{array}{c}\text { Post- } \\
\text { immunization }\end{array}$ \\
\hline 19 & 72 & $\begin{array}{ll}\text { C III } \\
\text { S I } \\
\text { S II }\end{array}$ & $\begin{array}{r}26 \\
0 \\
0\end{array}$ & $\begin{array}{r}16 \\
0 \\
0\end{array}$ \\
\hline 21 & 49 & $\begin{array}{ll}\text { C III } \\
\text { S I } \\
\text { S II }\end{array}$ & $\begin{array}{r}39 \\
0 \\
0\end{array}$ & $\begin{array}{r}36 \\
0 \\
0\end{array}$ \\
\hline 72 & 52 & $\begin{array}{ll}\text { C } & \text { VII } \\
\text { S } & \text { I } \\
\text { S } & \text { II }\end{array}$ & $\begin{array}{r}35 \\
0 \\
0\end{array}$ & $\begin{array}{r}42 \\
0 \\
0\end{array}$ \\
\hline 81 & 73 & $\begin{array}{ll}\mathrm{C} & \mathrm{VII} \\
\mathrm{S} & \mathrm{I} \\
\mathrm{S} & \mathrm{II}\end{array}$ & $\begin{array}{r}12 \\
0 \\
0\end{array}$ & $\begin{array}{r}12 \\
3 \\
0\end{array}$ \\
\hline 86 & 65 & $\begin{array}{ll}\text { C } & \text { VII } \\
\text { S } & \text { I } \\
\text { S } & \text { II }\end{array}$ & $\begin{array}{r}49 \\
0 \\
0\end{array}$ & $\begin{array}{r}18 \\
0 \\
0\end{array}$ \\
\hline 94 & 63 & $\begin{array}{ll}\text { C } & \text { VII } \\
\text { S } & \text { I } \\
\text { S } & \text { II }\end{array}$ & $\begin{array}{l}8 \\
0 \\
0\end{array}$ & $\begin{array}{r}18 \\
3 \\
3\end{array}$ \\
\hline 116 & 47 & $\begin{array}{ll}\text { C } & \text { VII } \\
\text { S } & \text { I } \\
\text { S } & \text { II }\end{array}$ & $\begin{array}{l}0 \\
0 \\
1\end{array}$ & $\begin{array}{l}0 \\
3 \\
3\end{array}$ \\
\hline 119 & 57 & $\begin{array}{ll}\text { C } & \text { VII } \\
\text { S } & \text { I } \\
\text { S } & \text { II }\end{array}$ & $\begin{array}{r}12 \\
0 \\
2\end{array}$ & $\begin{array}{r}10 \\
0 \\
0\end{array}$ \\
\hline $113 t$ & 48 & $\begin{array}{ll}\text { C VII } \\
\text { S I } \\
\text { S II }\end{array}$ & $\begin{array}{r}74 \\
0 \\
0\end{array}$ & $\begin{array}{l}35 \\
43 \\
32\end{array}$ \\
\hline
\end{tabular}

* See footnote, Table I.

$\dagger$ Patient had an episode of acute bacterial pneumonia during the test period.
TABLE VI

Antibody formation in patients with Hodgkin's disease or lymphosarcoma

\begin{tabular}{|c|c|c|c|c|}
\hline \multirow[b]{2}{*}{ Subject } & \multirow[b]{2}{*}{ Age } & \multirow[b]{2}{*}{$\begin{array}{c}\text { Antibody } \\
\text { to* }\end{array}$} & \multicolumn{2}{|c|}{$\begin{array}{l}\text { Micrograms of antibody } \\
\text { nitrogen per } 4 \text { milli- } \\
\text { liters of serum }\end{array}$} \\
\hline & & & $\begin{array}{c}\text { Pre- } \\
\text { immunization }\end{array}$ & $\underset{\text { immunization }}{\text { Post- }}$ \\
\hline $\begin{array}{c}20 \\
\text { Hodgkin's } \\
\text { disease }\end{array}$ & 20 & $\begin{array}{ll}\text { C III } \\
\text { S I I } \\
\text { S II }\end{array}$ & $\begin{array}{r}52 \\
0 \\
0\end{array}$ & $\begin{array}{r}28 \\
0 \\
7\end{array}$ \\
\hline $\begin{array}{c}31 \\
\text { Hodgkin's } \\
\text { disease }\end{array}$ & 48 & $\begin{array}{ll}\text { C } & \text { III } \\
\text { S } & \text { I } \\
\text { S II }\end{array}$ & $\begin{array}{r}68 \\
1 \\
0\end{array}$ & $\begin{array}{l}70 \\
32 \\
39\end{array}$ \\
\hline $\begin{array}{c}76 \\
\text { Hodgkin's } \\
\text { disease }\end{array}$ & 37 & $\begin{array}{ll}\text { C } & \text { VII } \\
\text { S } & \text { I } \\
\text { S } & \text { II }\end{array}$ & $\begin{array}{r}64 \\
1 \\
1\end{array}$ & $\begin{array}{r}64 \\
0 \\
1\end{array}$ \\
\hline $\begin{array}{c}18 \\
\text { Lympho- } \\
\text { sarcoma }\end{array}$ & 55 & $\begin{array}{ll}\text { C III } \\
\text { S I } \\
\text { S II }\end{array}$ & $\begin{array}{r}25 \\
0 \\
0\end{array}$ & $\begin{array}{r}22 \\
0 \\
17\end{array}$ \\
\hline $\begin{array}{c}74 \\
\text { Lympho- } \\
\text { sarcoma }\end{array}$ & 42 & $\begin{array}{ll}\text { C } & \text { VII } \\
\text { S } & \text { I } \\
\text { S } & I I\end{array}$ & $\begin{array}{r}61 \\
0 \\
8\end{array}$ & $\begin{array}{l}61 \\
25 \\
27\end{array}$ \\
\hline $\begin{array}{c}80 \\
\text { Lympho- } \\
\text { sarcoma }\end{array}$ & 34 & $\begin{array}{ll}\mathrm{C} & \mathrm{VII} \\
\mathrm{S} & \mathrm{I} \\
\mathrm{S} & \mathrm{II}\end{array}$ & $\begin{array}{r}48 \\
0 \\
1\end{array}$ & $\begin{array}{r}50 \\
1 \\
0\end{array}$ \\
\hline $\begin{array}{c}50 \\
\text { Lympho- } \\
\text { sarcoma }\end{array}$ & 74 & $\begin{array}{ll}\text { C VII } \\
\text { S I } \\
\text { S II }\end{array}$ & $\begin{array}{l}\mathbf{5} \\
\mathbf{0} \\
\mathbf{0}\end{array}$ & $\begin{array}{r}13 \\
3 \\
40\end{array}$ \\
\hline
\end{tabular}

* See footnote, Table I.

did not receive cortisone. However, almost half of the values were well above the normal range of antibody response. The dosage of cortisone used in treating patients with acute leukemia was considerably larger than the dosage used in the treatment of rheumatoid arthritis and this may have influenced the results.

\section{SUM MARY}

Antibody formation to pneumococcus capsular polysaccharides I and II has been studied in a group of human subjects with leukemia and other lymphomatous disease, using quantitative immunochemical techniques. Nine of 11 patients with untreated acute leukemia had unusually large antibody responses. These responses were impaired in seven patients with acute leukemia receiving cortisone. Eight of nine patients with chronic lymphatic leukemia exhibited little or no antibody response. Seven patients with chnonic myeloid leukemia, three patients with Hodgkin's disease, and four patients with lymphosarcoma had antibody responses essentially within the normal range. 


\section{REFERENCES}

1. McMaster, P. D., and Hudack, S. S., The formation of agglutinins within lymph nodes. J. Exper. Med. 1935, 61, 783.

2. Ehrich, W. E., and Harris, T. N., The site of antibody formation. Science, 1945, 101, 28.

3. Bjфrneboe, M., and Gormsen, H., Experimental studies on the role of plasma cells as antibody producers. Acta path. et microbiol. Scandinav., 1943, 20, 648.

4. Fagraeus, A., The plasma cellular reaction and its relation to the formation of antibodies in vitro. J. Immunol., 1948, 58, 1.

5. Sabin, F. R., Cellular reactions to dye-protein with a concept of the mechanism of antibody formation. J. Exper. Med., 1939, 70, 67.

6. Moreschi, C., Uber antigene und pyrogene Wirkung des Typhusbaccillus bei leukämischen Kranken. Ztschr. f. Immunitatsforsch. u. exper. Therap., 1914, 21, 410.

7. Howell, K. M., The failure of antibody formation in leukemia. Arch. Int. Med., 1920, 26, 706.

8. Chung, H. L., and Reimann, H. A., Antibody formation in kala-azar. Arch. Int. Med., 1930, 46, 782.

9. Evans, R. W., The antibody response in cases of radiation lymphopenia, and in the reticuloses. $\mathrm{J}$. Path. \& Bact., 1948, 60, 123.

10. Rotky, H., Uber die Fahigheit von Leukämikern Antikörper zu erzeugen. Zentralbl. f. inn. Med., 1914, 35, 953.
11. Bernstein, A., The diagnostic importance of the heterophile antibody test in leukemia. J. Clin. Invest., 1934, 13, 677.

12. Weinstein, G. L., and Fitz-Hugh, T., Jr., The heterophil antibody test in leukemia and leukemoid conditions. Am. J. M. Sc., 1935, 190, 106.

13. Goldman, R., Fishkin, B. G., and Peterson, E. T., The value of the heterophile antibody reaction in the lymphomatous diseases. J. Lab. \& Clin. Med., 1950, 35, 681.

14. Southam, C. M., Goldsmith, Y., and Burchenal, J. H., Heterophile antibodies and antigens in neoplastic diseases. Cancer, 1951, 4, 1036.

15. Heidelberger, M., MacLeod, C. M., Hodges, R. G., Bernhard, W. G., and DiLapi, M. M., Antibody formation in men following injection of four typespecific polysaccharides of pneumococcus. J. Exper. Med., 1947, 85, 227.

16. Larson, D. L., and Tomlinson, L. J., Quantitative antibody studies in man. I. The effect of adrenal insufficiency and of cortisone on the level of circulating antibodies. J. Clin. Invest., 1951, 30, 1451.

17. Larson, D. L., and Tomlinson, L. J., Quantitative antibody studies in man. II. The relation of the level of serum proteins to antibody production. J. Lab. \& Clin. Med., 1952, 39, 129.

18. Heidelberger, M., The chemical nature of immune substances. Physiol. Rev., 1927, 7, 107.

19. Heidelberger, M., DiLapi, M. M., Siegel, M., and Walter, A. W., Persistence of antibodies in human subjects injected with pneumococcal polysaccharides. J. Immunol., 1950, 65, 535. 